\title{
SOMATIC PARAMETERS OF 17 YEAR OLD SOCCER PLAYERS IN THE OLDER YOUTH CATEGORY IN RELATION TO SPORTS PERFORMANCE
}

\author{
Petr Kutáč
}

Human Motion Diagnostic Center, University of Ostrava, Ostrava, Czech Republic

Submitted in February, 2013

\begin{abstract}
BACKGROUND: Somatic parameters are included not only in the general structure of sporting performance, but also in the structure of sporting performance in soccer. In light of this structure, higher performance players should have better somatic performance prerequisites, and their somatic parameters should differ from players with lower performance levels.
\end{abstract}

OBJECTIVE: The aim of the study is to assess the somatic parameters of players with different performance levels. METHODS: The research included 90 soccer players in the age of 17 years in three performance categories playing in the junior competition in the Czech Republic. Average age of the individual levels - highest performance $17.61 \pm 0.48$, middle performance $17.50 \pm 0.50$, lowest performance $17.50 \pm 0.50$ years. The following was monitored - basic anthropometric parameters (body weight, body height), somatotype (Heath-Carter), representation of body fat (BF), fat free mass (FFM) and the total body water (TBW). The Tanita 418 MA tetrapolar bioelectrical impedance (BIA) scale was used for the determination of the representation of BF and the TBW. All players were measured at the beginning of the competition period in the same year. All measurements were implemented in the morning hours by the same person with corresponding experience.

RESULTS: The average values of somatic parameters measured in the individual performance categories show that we can only consider them to be an indicator of sporting performance up to a particular performance level. The boundary was the middle performance level (teams playing regional competition) as their mean values of the monitored somatic parameters significantly differed from the mean values of players at the lowest performance level (teams playing at the district and municipal levels) but they did not differ when compared with the mean values of the players at the highest performance level (teams playing the top junior league).

CONCLUSIONS: From the middle performance level (regional competition), we do not consider the monitored body composition parameters as crucial in terms of individual playing performance.

Keywords: Sports games, sporting performance, body composition, somatotype.

\section{INTRODUCTION}

Somatic parameters are one of the factors that predetermine the level of physical condition and basic motoric performance (Jürimäe \& Jürimäe, 2001; McArdle, Katch, \& Katch, 2007; Wilmore \& Costill, 1994). This is also confirmed by many authors and studies that deal with the effect of somatic parameters on physical condition or performance in motoric tests (Malina, Bouchard, \& Bar-Or, 2004; Mota et al., 2002; Saar \& Jürimäe, 2001). The aforementioned studies show that the increasing share of $\mathrm{BF}$ and endomorphic components of somatotype particularly show a negative effect,

\footnotetext{
* Address for correspondence: Petr Kutáč, Human Motion Diagnostic Center, University of Ostrava, Varenská 40a, 70200 Ostrava, Czech Republic. E-mail: petr.kutac@osu.cz
}

namely on the motoric performance related to moving one's body. At the same time, it limits the speed and accuracy of the movement execution and also limits the endurance capacity. Some authors state the amount of body fat as a limiting factor of aerobic ability (Maffeis et al., 1994). The relation between physical condition and somatic parameters is also demonstrated by their incorporation in test elements monitoring physical condition, such as Eurofit (Saar \& Jürimäe, 2001).

Somatic parameters are one of the crucial aspects of sporting performance in sports where the individual performance depends on the level of one's motoric ability and physical condition (Zanovec, Johnson, Marx, Keenan, \& Tuuri, 2009). This fact is reflected in the inclusion of somatic parameters, together with conditioning, technique, tactics and psychological factors not only in the general structure of sport performance (Dovalil et al., 2002; Grosser \& Zintl, 1994; Schnabel, Harre, \& Krug, 2003), but also in the structure of sport 
performance in a range of sports, including sports games. In sports games, for their specificity, sports performance is called playing performance, which is made up of two performance categories - individual playing performance and team playing performance (Carron, Hausenblas, \& Eys, 2005; Green, Pivarnik, Carrier, \& Womack, 2006; Schnabel, Harre, \& Krug, 2003). When evaluating individual players, we evaluate individual playing performance, as this determines the team playing performance, which is primarily a socio-psychological dimension. In soccer, amongst the determining factors that allow players to develop and implement individual playing performance the authors include biomechanical, psychological, bio-energy and somatic (sometimes referred to as somatic) factors, (Malone, Collins, Thompson, \& Barfield, 2004; Rampinini, Impellizzeri, Castagna, Coutts, \& Wisløff, 2009).

It is most often the share of body fat and the body constitution (somatotype). As those parameters should have a significant effect with regard to the character of the executed performance (Arroyo, Gonzalez-de-Suso, Sanchez, Ansotegui, \& Rocandio, 2008; Moreira, 2008; Rico-Sanz, 1998; Sutton, Scott, Wallace, \& Reilly, 2009). With respect to the mentioned structure of the sporting performance and the results of the aforementioned studies dealing with the development of somatic parameters, the players at a higher performance level should have more suitable somatic prerequisites for performance and their somatic parameters should significantly differ from players at a lower performance level. The submitted study will thus try to verify the significance of the representation of somatic parameters in the structure of the sporting performance in soccer.

The aim of the study is to assess the somatic parameters of players with different performance levels.

\section{METHODOLOGY}

\section{The research group}

The research included players of older junior teams in 3 performance levels according to the directives of the Football Association of the Czech Republic. We selected the age category of older juniors with regard to the estimated time of the players' involvement in the training process. We can estimate that the players have been in the training process for 11 to 12 years. We believe that the duration of the effects of specific soccer training could be reflected in the body structure of the players. The highest performance level included teams playing the highest junior league (Czech Republic). The middle performance level included teams playing the regional competition (Czech Republic - MoravianSilesian Region) and the lowest performance level included teams playing at the district and municipal level (district of Ostrava). The performance criterion for incorporating a player into one of the three determined performance levels was his activity in the basic team set playing at one of the three stated competition levels. We determined the fact that the incorporation of a player in a team at a particular performance level has a sufficient evidential value of his soccer performance. 3 clubs were selected from in each performance. Each performance and age category included 30 players; the total number of tested players was 90 . There were no foreign players on any of the teams; all of the players were Czech. Average age of the individual levels - highest performance $17.61 \pm 0.48$, middle performance $17.50 \pm 0.50$, lowest performance $17.50 \pm 0.50$ years.

\section{Procedure}

Basic anthropometric parameters (body weight, body height) and body composition - body fat (BF), fat free mass (FFM), total body water (TBW) and somatotype were measured. Body composition was measured using the tetrapolar bioimpedance (BIA) Tanita 418 MA scale (Tanita Corporation, Japan). This device is equipped with eight scanning electrodes and uses a frequency of $50 \mathrm{kHz}$ for measuring. For measuring, this is defined as the five-cylinder model, which does not include the head.

Somatotype was determined using the Heath and Carter method (Heath \& Carter, 1967). The anthropometric data for the calculation of the somatotype were processed by a computer program - Somatotype calculation and analysis (Sedat Technologies, 2001). In order to assess the adequacy of body weight in view of body height, instead of body mass index (BMI) we used the fat free mass index (FFMI), which reflects greater musculature in individual athletes and assesses fat free mass. In order to evaluate fat mass, we used the body fat mass index (BFMI) (Hattori, Tatsumi, \& Tanaka, 1997).

The measurements of all players were executed at the beginning of the competitive period in the same year. The measurements of all parameters were always taken in the morning, under the strict observance of all standard conditions for measurement (BIA method). The anthropometric measurements for the calculation of the somatotype were always carried out by the same person with corresponding experience.

\section{Statistical analysis}

The level of position (arithmetic mean) and the level of variability (standard deviation) were determined for each metric value.

We used the one way ANOVA to verify the statistical significance of the differences in the means of the monitored parameters of body composition in the research sets. Distant observations were identified by box 
plots. The normality of distribution was verified by the Shapiro-Wilk Test, which is one of the conditions of using ANOVA. Another condition of ANOVA is the homoscedasticity (homogeneity) of variance, which was verified using Levene's Test. The statistical significance in parameters that met the condition of homoscedasticity was verified by the F Statistic and in parameters that did not meet the condition by the Brown-Forsythe Statistic. We used post hoc tests to detect what performance levels are responsible for the found differences. The Tukey Test was used for parameters that met the condition of homoscedasticity and Games-Howel Test for parameters that did not meet this condition. The following level of the statistic significance was selected for all tests used $-\alpha=.05$.

In statistically significant differences in the means of the monitored parameters, we also evaluated the objective significance of the mean results and standard deviations. For that evaluation we used the Effect of Size according to Cohen $\left(d=\left(M_{1}-M_{2}\right) / S D\right)$, where

$$
S D=\sqrt{\frac{n_{1} \cdot S D_{1}^{2}+n_{2} \cdot S D_{2}^{2}}{n_{1}+n_{2}}}
$$

Recommendation for Effect of Size $(E S)$ evaluated by Cohen's $d-0.2=$ small change, $0.5=$ medium change, 0.8 = large change according to (Cohen, 1988). The statistical processing of the results was executed with the use of the PASW SPSS 19.0 program.
The normality of the development of the basic anthropometric indicators (body weight, body height) was evaluated with the use of percentile graphs for the Czech population (Bláha, Vignerová, Riedlová, Kobzová, \& Krejčovský, 2003).

The study protocol was approved by the Ethics and Research Committee of the University of Ostrava. All participants signed an informed consent form.

\section{RESULTS}

The measured values somatic parameters are presented in Table 1.

Only the values for body height and mesomorphic somatotype components meet the condition of homoscedasticity of variance based on the results of the Levene's Test. Other parameters do not meet this condition (Table 2). Therefore, we only used the F Statistic for body weight and mesomorphic components to verify the statistical significance of the differences in the means. We used the Brown-Forsythe Statistic for other parameters (Table 2). Based on the results of F statistic and Brown-Forsythe statistic, the parameters of body height, body weight, FFM (kg), FFMI and TBW (kg) were not tested via post hoc tests. Statistically relevant differences were not ascertained for these parameters (Table 2). For the remaining parameters, the statistical relevance of the differences in averages between individual performance categories was verified using the Games-Howel test. The Tukey test (Table 3) was only used for mesomorphic components.

Table 1

Somatic parameters (Mean $\pm S D$ ) of the players

\begin{tabular}{lccc}
\hline & \multicolumn{3}{c}{ Performance level } \\
\cline { 2 - 4 } Parameter & Highest $(n=30)$ & Middle $(n=30)$ & Lowest $(n=30)$ \\
\hline BH $(\mathrm{cm})$ & $179.91 \pm 6.27$ & $180.93 \pm 5.97$ & $177.96 \pm 6.39$ \\
BW $(\mathrm{kg})$ & $70.54 \pm 5.67$ & $70.16 \pm 7.67$ & $75.36 \pm 13.29$ \\
BFMI $\left(\mathrm{kg} / \mathrm{m}^{2}\right)$ & $2.82 \pm 0.55$ & $2.98 \pm 0.70$ & $\mathbf{4 . 3 0} \pm 1.66$ \\
FFMI $\left(\mathrm{kg} / \mathrm{m}^{2}\right)$ & $18.96 \pm 1.06$ & $18.46 \pm 1.75$ & $19.40 \pm 1.89$ \\
BF $(\mathrm{kg})$ & $9.11 \pm 1.75$ & $9.77 \pm 2.26$ & $\mathbf{1 3 . 7 4} \pm 5.67$ \\
BF $(\%)$ & $12.96 \pm 2.00$ & $13.80 \pm 2.23$ & $\mathbf{1 7 . 6 0} \pm 4.57$ \\
FFM $(\mathrm{kg})$ & $61.42 \pm 4.90$ & $60.39 \pm 5.97$ & $61.62 \pm 8.21$ \\
FFM $(\%)$ & $87.04 \pm 2.00$ & $86.22 \pm 2.21$ & $\mathbf{8 2 . 4 1} \pm 4.56$ \\
TBW $(\mathrm{kg})$ & $44.93 \pm 3.59$ & $44.21 \pm 4.37$ & $45.09 \pm 6.00$ \\
TBW $(\%)$ & $63.72 \pm 1.45$ & $63.12 \pm 1.63$ & $\mathbf{6 0 . 3 0} \pm 3.35$ \\
Endomorphy & $2.73 \pm 0.69$ & $3.01 \pm 0.82$ & $\mathbf{4 . 2 8} \pm 1.63$ \\
Mesomorphy & $4.50 \pm 1.04$ & $4.96 \pm 1.19$ & $\mathbf{5 . 1 8} \pm 0.90$ \\
Ectomorphy & $3.37 \pm 0.89$ & $3.65 \pm 1.25$ & $\mathbf{2 . 6 1} \pm 1.22$ \\
\hline
\end{tabular}

Note. $\mathrm{BH}=$ body height, $\mathrm{BW}=$ body weight $\mathrm{BFMI}=$ body fat mass index, FFMI $=$ fat free mass index, $\mathrm{BF}=$ body fat, $\mathrm{FFM}=$ fat free mass, $\mathrm{TBW}=$ total body water Values with statistically significant differences are in boldface. 
Table 2

Results of the test verification of homoscedasticity and mean significance

\begin{tabular}{|c|c|c|c|c|c|c|}
\hline \multirow[b]{2}{*}{ Parameter } & \multicolumn{2}{|c|}{ Levene's test } & \multicolumn{2}{|c|}{$F$ statistic } & \multicolumn{2}{|c|}{ Brown-Forsythe statistic } \\
\hline & Stat. & Sig. & Stat. & Sig. & Stat. & Sig. \\
\hline $\mathrm{BH}(\mathrm{cm})$ & 0.018 & .982 & 1.710 & .187 & & \\
\hline BW (kg) & 10.831 & $<.001 *$ & & & 2.731 & .074 \\
\hline BFMI $\left(\mathrm{kg} / \mathrm{m}^{2}\right)$ & 18.627 & $<.001 *$ & & & 16.272 & $<.001^{*}$ \\
\hline FFMI $\left(\mathrm{kg} / \mathrm{m}^{2}\right)$ & 5.533 & $.005^{*}$ & & & 2.467 & .092 \\
\hline $\mathrm{BF}(\mathrm{kg})$ & 20.461 & $<.001^{*}$ & & & 13.657 & $<.001^{*}$ \\
\hline BF (\%) & 11.040 & $<.001^{*}$ & & & 18.230 & $<.001^{*}$ \\
\hline FFM (kg) & 5.213 & $.007 *$ & & & 0.300 & .742 \\
\hline FFM (\%) & 11.050 & $<.001^{*}$ & & & 18.325 & $<.001^{*}$ \\
\hline TBW (kg) & 5.189 & $<.001^{*}$ & & & 0.282 & .755 \\
\hline TBW (\%) & 10.974 & $<.001^{*}$ & & & 18.480 & $<.001^{*}$ \\
\hline Endomorphy & 15.036 & $<.001^{*}$ & & & 15.811 & $<.001^{*}$ \\
\hline Mesomorphy & 1.227 & .298 & 3.386 & $.038^{*}$ & & \\
\hline Ectomorphy & 4.479 & $.014 *$ & & & 6.681 & $.002 *$ \\
\hline
\end{tabular}

Note. Stat. $=$ result of test, Sig. $=$ result significance.

$* p<.05$

Table 3

Results of post hoc tests

\begin{tabular}{|c|c|c|c|c|}
\hline \multirow[b]{2}{*}{ Parameter } & \multirow[b]{2}{*}{ Performance level } & \multicolumn{2}{|c|}{ Post hoc tests } & \multirow{2}{*}{$\begin{array}{l}\text { Effect of size } \\
(\text { Cohen's } d)\end{array}$} \\
\hline & & Games-Howell & Tukey & \\
\hline \multirow[t]{3}{*}{ BFMI $\left(\mathrm{kg} / \mathrm{m}^{2}\right)$} & Lowest-Highest & $<.001^{*}$ & & 1.19 \\
\hline & Lowest-Middle & $<.001^{*}$ & & 1.03 \\
\hline & Highest-Middle & .572 & & - \\
\hline \multirow[t]{3}{*}{$\mathrm{BF}(\mathrm{kg})$} & Lowest-Highest & .001 & & 1.10 \\
\hline & Lowest-Middle & $.003^{*}$ & & 0.91 \\
\hline & Highest-Middle & .427 & & - \\
\hline \multirow[t]{3}{*}{$\mathrm{BF}(\%)$} & Lowest-Highest & $<.001^{*}$ & & 1.31 \\
\hline & Lowest-Middle & $.001^{*}$ & & 1.05 \\
\hline & Highest-Middle & .276 & & - \\
\hline \multirow[t]{3}{*}{ FFM (\%) } & Lowest-Highest & $<.001^{*}$ & & 1.31 \\
\hline & Lowest-Middle & $.001^{*}$ & & 1.06 \\
\hline & Highest-Middle & .284 & & - \\
\hline \multirow[t]{3}{*}{ TBW (\%) } & Lowest-Highest & $<.001^{*}$ & & 1.32 \\
\hline & Lowest-Middle & $.001^{*}$ & & 1.07 \\
\hline & Highest-Middle & .281 & & - \\
\hline \multirow[t]{3}{*}{ Endomorphy } & Lowest-Highest & $<.001^{*}$ & & 1.23 \\
\hline & Lowest-Middle & $.002 *$ & & 0.98 \\
\hline & Highest-Middle & .319 & & - \\
\hline \multirow[t]{3}{*}{ Mesomorphy } & Lowest-Highest & & $.035^{*}$ & 0.69 \\
\hline & Lowest-Middle & & .713 & - \\
\hline & Highest-Middle & & .203 & - \\
\hline \multirow[t]{3}{*}{ Ectomorphy } & Lowest-Highest & $.018^{*}$ & & 0.71 \\
\hline & Lowest-Middle & $.006^{*}$ & & 0.84 \\
\hline & Highest-Middle & .575 & & - \\
\hline
\end{tabular}

Note. $* \mathrm{p}<.05$ 
The measured differences between the mean values of the body height and weight at the individual performance levels are not statistically significant based on the results of the $F$ Statistic and Brown-Forsythe Statistic.

The mean values of the percentage representation of BF increase with the decreasing performance level, but we can still call them standard at all performance levels according to the software of the Tanita $418 \mathrm{MA}$ device. However, this evaluation is given by the wide range and a high limit value of the standard (20\%). Professional literature most often states that the mean value of the $\mathrm{BF}$ representation for this age group is $15 \%$ (Heyward \& Wagner, 2004; McArdle, Katch, \& Katch, 2007; Lohman, 1992; Lohman, Houtkooper, \& Going, 1997). However, the mean value of players at the lowest performance level exceeds that. A more detailed analysis of the BF representation of the individual players showed that the $15 \%$ level was exceeded in $21(70 \%)$ players at the lowest performance level and in 4 (13\%) players at the middle performance level. As for players at the highest performance level, none of the players exceeded this value. The statistically significantly higher value of the BF representation at the lowest performance level is fully demonstrated here in comparison with the players at the middle and highest performance level. Also, the objective significance was confirmed and we can call it significant based on the results of the Effect of Size (in percentage, the Cohen value $d$ was 1.05 and 1.31 , and percentage in kilograms was 0.91 and 1.10). The average values of the proportion of fat fraction also correspond to the average values of FFM percentage. As with body fat proportion, the values measured at the lowest performance category are also

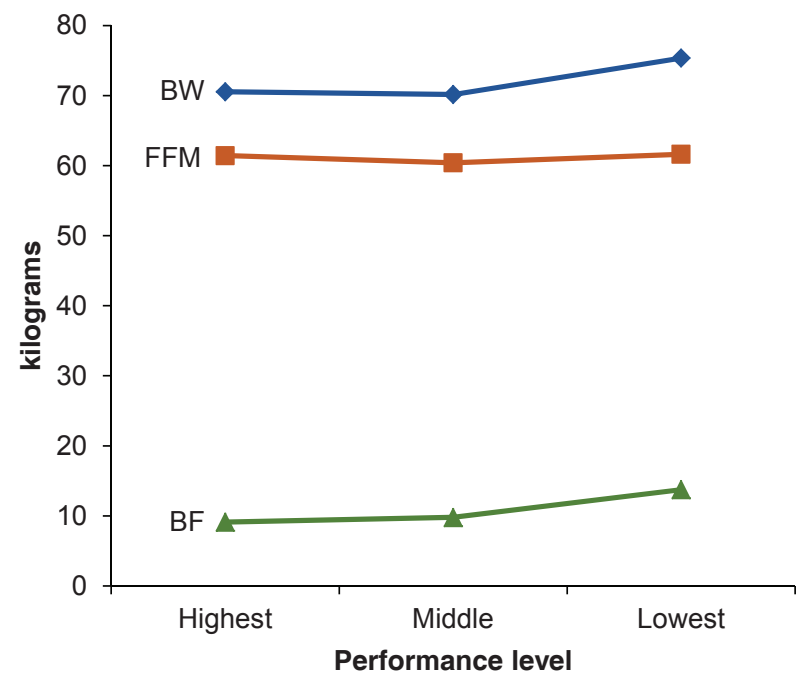

Figure 1. Proportion of body fat and fat free mass to total body weight in individual performance categories (BW = body weight, $\mathrm{FFM}=$ fat free mass, $\mathrm{BF}=$ body fat $)$ statistically and materially different (the Cohen value $d$ is 1.06 and 1.31, Table 3). The results of the differences in the average BF representation are reflected in the average body weight values. The highest body weight found in players of lowest performance level is caused by an increased proportion of BF, not FFM, which manifested in these players as a rise in the percentage of BF and decrease in FFM (Figure 1,2).

We calculated the FFMI and BFMI indexes from the values of body height, FFM and BF, as these indexes are better for evaluating adequate body mass in athletes. We did not find statistically relevant differences in the FFMI average values in individual performance categories, which also correspond to the absence of statistically relevant differences in body height and FFM. Statistically relevant differences were found in the fat fraction mass in the BFMI index. The statistically relevant difference in this index was manifested in its higher value for the lowest performance category. Statistical relevance is also accompanied by a high material relevance (Cohen $d$ has the value of 1.03 and 1.19, Table 3).

The found mean values of the TBW representation correspond with values commonly measured in men in this age category (Forjasz, 2011; Martarelli, Martarelli, \& Pompei, 2008; Rush, Chhichhia, Kilding, \& Plank, 2010). The found differences between the individual performance levels are simile to the body fat representation. The mean value in players at the lowest performance level is statistically and objectively significant (Cohen's $d$ was 1.07 and 1.32, Table 3). With regard to the used method (BIA) when the TBW is the primarily measured parameters, it is a corresponding result.

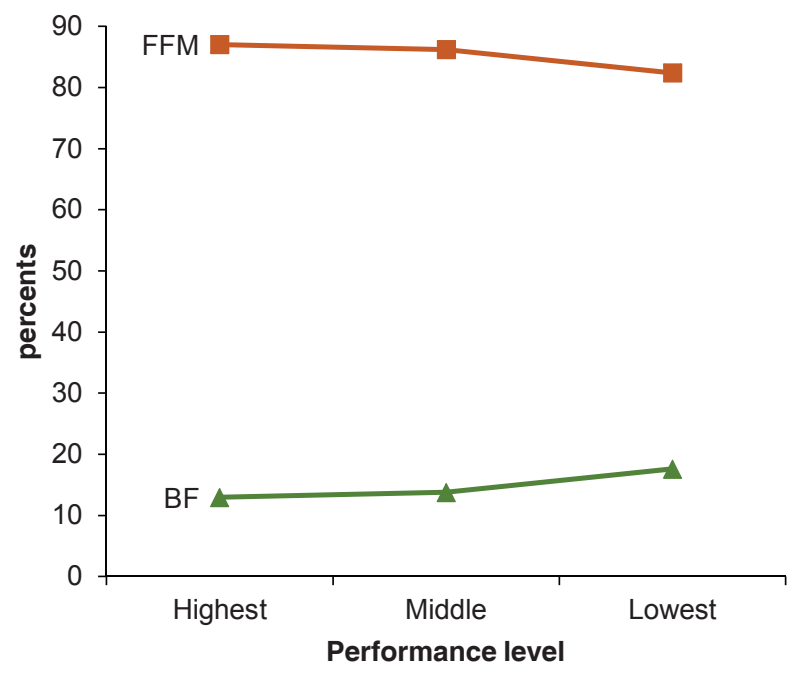

Figure 2. Percentage representation of body fat and fat free mass in individual performance categories $(\mathrm{FFM}=$ fat free mass, $\mathrm{BF}=$ body fat $)$ 
We did not find any statistically significant differences between the mean values of the individual somatotype components in players at the highest and middle performance level. The fact that the mean somatotypes at both performance levels are similar is also documented by their incorporation in the same somatotype category (the boundary between the mesomorphic, ectomorphic mesomorphic category) and also by their position in the somatograph (Figure 3).

The mean somatotype at the lowest performance level belongs in the endomorphic mesomorph category. The mean value of the mesomorphy component at this performance level is the highest but this higher value is accompanied with a high endomorphy component value. However, it is only statistically significantly different in comparison with the mean value at the highest performance level. The objective significance can be labelled as medium (Cohen's $d$ had the value of 0.69).

The endomorphy component is statistically significantly different in comparison with the mean values of players at the highest and middle performance level. The objective significance can be labelled as significant; the value of Cohen's $d$ was 0.99 and 1.23 (Table 3). We did not find such a high mean value even in studies monitoring regular population; authors usually state endomorphy component value of up to 3 points (da Silva Vasques, Lopes, Teixeira e Seabra, da Silva, \& Maia, 2006; Peeters et al., 2003; Viviani, 2001). The value of 4-4.5 points is regarded as an endomorphy component value signaling increased body weight (Lohman, 1989), we found this value in 13 players $(43.33 \%)$ at the lowest performance level. We found a value exceeding 5 points in 11 players $(36.66 \%)$ at the lowest performance level. This frequency also corresponds with the number of players in which we found BMI values signaling increased body weight. The high value of the endomorphy component fully corresponds with the results of the body fat representation.

As for the mean values of the ectomorphy component, the lower mean value of players at the lowest performance level is statistically significantly different. The objective significance ranges from 0.71 to $0.84 \mathrm{Co}-$ hen's $d$ (Table 3).

\section{DISCUSSION}

The players we monitored may be considered to be average individuals in basic anthropomorphic parameters (body weight and body height) in the given age category in the Czech Republic. The found mean values of these parameters are within the range of mean values and they are localized in growth graphs in the area of 50 percentile population (Bláha, Vignerová, Riedlová, Kobzová, \& Krejčovský, 2003). Only the body weight value in players at the lowest performance level is at the limit of the mean value ( 75 percentile). For the body height of this age group, standard values range from 176 to $185 \mathrm{~cm}$, and for body mass $64-76 \mathrm{~kg}$. The average BFMI index values calculated from body height and body fat correspond for all performance levels to the values reported in a general healthy population. These values are reported in the range of 1.5 to $5.2 \mathrm{~kg} / \mathrm{m}^{2}$ (Bahadori, Uitz, Toninger-Bahadori, Pestemer-Lach, Trummer, Thonhofer, Brath, \& Schaflinger, 2006; Hattori,

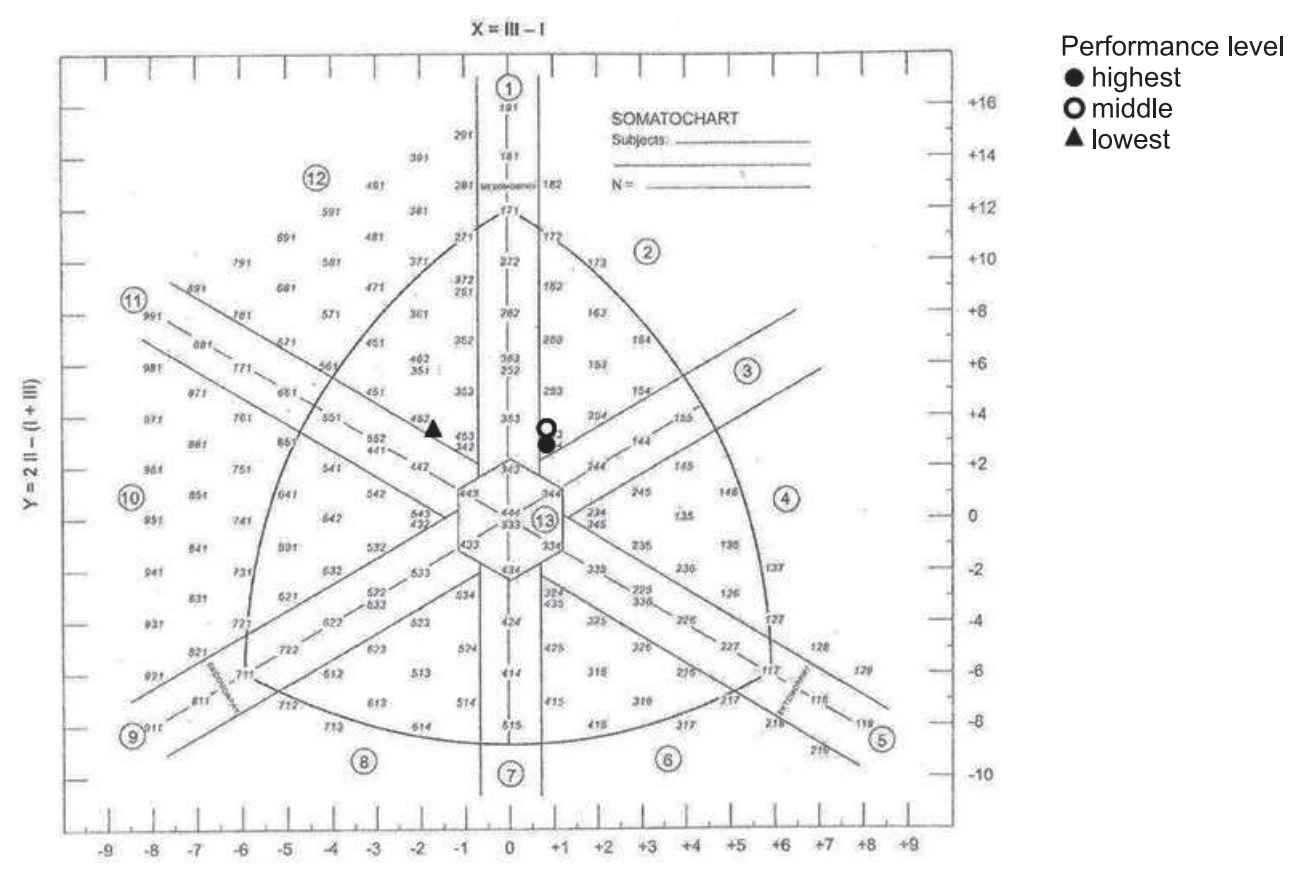

Figure 3. Average performance category somatotypes 
Tatsumi, \& Tanaka, 1997). In the highest and medium performance categories, this value was not exceeded by any player. In the lowest performance category it was exceeded by 8 players $(26.66 \%)$. These were the same players who exceeded the standard value of the percentage of $\mathrm{BF}$ representation, which is specified in the software of the Tanita MA 418 device (20\% BF). The average FFMI index values, which are calculated from the FFM percentage and body height also correspond to the values reported for a normal healthy population (Hattori, Tatsumi, \& Tanaka, 1997; Kyle, Schulz, Dupertius, \& Richard, 2003). These values are presented in the range from 16.5 to $19.9 \mathrm{~kg} / \mathrm{m}^{2}$. In the highest performance category, the value of $19.9 \mathrm{~kg} / \mathrm{m}^{2}$ was exceed by 6 players (20\%); however, the higher FFMI value in 4 players was accompanied by a higher BF percentage, and higher endomorphic component value than the average value of the entire group. For players in the middle performance category an FFMI value higher than $19.9 \mathrm{~kg} / \mathrm{m}^{2}$ was detected in 4 players $(13.33 \%)$, and 3 of them were associated with an increased BF percentage and higher endomorphy. In the lowest performance category, the indicated value was exceeded by 12 players (40\%) and all of them had a higher BF representation and higher endomorphic component value. The increased proportion of muscle mass, which is signalled by the FFMI index value of these players with regard to the value of BF percentage, which is also reflected in the increased endomorphy, may not be beneficial to their physical performance.

As the monitored players are in an age category when there is a significant deceleration or even stagnation in the development of the anthropometric and somatic parameters (Malina, Bouchard, \& Bar-Or, 2004), we can compare the monitored parameters with values that are available in adult players. Professional literature shows model values where the total body fat representation parameter does not exceed 10\% (Heyward \& Wagner, 2004; Malina, Bouchard, \& Bar-Or, 2004; McArdle, Katch, \& Katch, 2007). These model values also correspond with values that are directly stated in professional studies of the volume of fat representation in the total body weight in elite soccer players. Authors of those studies, using BIA or DXA methods, state optimal BF representation in the range of $8-12 \%$, in relation to the field position and season (Ostojic, Stojanovic, Jukic, Pasalic, \& Jourkesh, 2009; Silvestre, West, Maresh, \& Kraemer, 2006; Sutton, Scott, Wallace, \& Reilly, 2009). If we consider the value of $12 \%$ to be the limit value for the optimal BF representation, then 11 players at the highest performance level (36.66\%), 9 players at the middle performance level $(30 \%)$ and only 2 players at the lowest performance level (6.66\%) had optimal BF representation.
The low BF representation in elite soccer players also corresponds with the values of the endomorphy component, which are available in professional studies. Authors state their values within the range of 2.0-2.6 points (Casajús, 2001; Gil, Gil, Ruiz, Irazusta, \& Irazusta, 2007; Hencken, 2004; Raschka \& Wolthausen, 2007). The values of the BF representation as well as the endomorphy component correspond with the character of the sporting performance in soccer. This namely includes running at various speed and intensity. In contemporary modern soccer when several players are involved in the individual stages of the game at the same time, there is an increase in the completed kilometric performance during a match. Authors state an overall kilometric performance in elite teams to be between 9 and 13 kilometers in relation to the field position (Stolen, Chamari, Castagna, \& Wisloff, 2005). Also, there is an increase in the ratio of running at various speed and intensity to walking and standing. These changes are not only reflected in the aforementioned values of $\mathrm{BF}$ representation and endomorphy component, but also in the decrease of the mesomorphy component and a slight increase in the ectomorphy component. Authors state that the parameters of elite soccer players are similar to the parameters of mediumdistance runners (Malina, Bouchard, \& Bar-Or, 2004). Those trends are also confirmed by (Moreira, 2008) who monitored the development of somatotypes in world-class players between 1970 and 1998. Professional studies imply that the value of the mesomorphy component ranges from 4.0 to 4.9 points and the ectomorphy component from 2.0 to 2.9 points (Casajús, 2001; Gil, Gil, Ruiz, Irazusta, \& Irazusta, 2007; Hencken, 2004; Raschka \& Wolthausen, 2007). If we consider the value of the endomorphy component of 2.6 points as the limit value for optimal mesomorphy, then the endomorphy value of up to 2.6 points was found in 18 players $(60 \%)$ at the highest performance level, 15 players $(50 \%)$ at the middle performance level and 7 players $(23.33 \%)$ at the lowest performance level. The increasing value of the mesomorphy component with the decreasing performance level in our players is accompanied by a significant increase in the endomorphy component.

As the somatotype needs to be evaluated as a whole, we performed an analysis of the somatotype of the individual players we monitored. Based on the presented values of the individual components of somatotypes ( 2.0 to $2.6-4.0$ to $4.9-2.0$ to 2.9 ), the values for an optimal somatotype are met by 7 players $(23.33 \%)$ at the highest performance level, 4 players $(13.33 \%)$ at the middle performance level and no players at the lowest performance level. 


\section{Restriction of the results}

The results obtained may be influenced by the scope of the selected set and by the fact that the players came from one region. In spite of that we can consider the players to be a particular representative set of players in the given age category of the Moravian-Silesian Region, which is one of the 14 regions representing the territorial structure of CMFS (the Football Association of the Czech Republic).

The results of the evaluation and the differences in the somatic parameters between the individual performance levels may also be influenced by the selection of those parameters. For instance, we could not perform the evaluation of the ECM/BCM index (a ratio between the extracellular and intracellular mass) which is also considered to be a criterion for the evaluation of the prerequisite to a physical performance. The used equipment we had available (Tanita 418 MA) does not allow taking measurements of such parameters.

In addition, the diet of the monitored players could also have a significant effect on the results. We did not observe the diet of the players; however, the soccer clubs did not provide any meals to the players and they did not receive any food supplements or dietary recommendations.

\section{CONCLUSION}

The mean values of basic anthropometric parameters (body height and mass) do not statistically significantly differ in the observed performance categories of players. In all of the observed groups the ascertained average values correspond to the standard values of the Czech population in this age group.

For other somatic parameters, the mean values of players in the lowest performance category statistically and substantively differed from other performance levels. The only exception was the FFMI index, where there were no differences observed, and the value of mesomorphic component, where only the mean values of players from the highest and lowest performance categories statistically and substantively differed.

From the middle performance level (regional competition), we do not consider the monitored body composition parameters as crucial in terms of individual playing performance. This finding is in accordance with the findings presented in the professional study that is also involved with the body composition of junior age soccer players (Botek et al., 2010).

\section{REFERENCES}

Arroyo, M., González-de-Suso, J. M., Sanchez, C., Ansotegui, L., \& Rocandio, A. M. (2008). Body image and body composition: Comparisons of young male elite soccer players and controls. International Journal of Sport Nutrition and Exercise Metabolism, 18(6), 628-638.

Bahadori, B., Uitz, E., Toninger-Bahadori, K., Pestemer-Lach, I., Trummer, M., Thonhofer, R., ... Schaflinger, E. (2006). Body composition: The fatfree mass index (FFMI) and distribution among the adult Austrian population - results of cross-sectional pilot study. International Journal of Body Composition Research, 4(3), 123-128.

Bláha, P., Vignerová, J., Riedlová, J., Kobzová, J., \& Krejčovský, L. (2003). National anthropological research of children and young people for 2001. Česko-slovenská pediatrie, 58(12), 766-770.

Botek, Z., Gába, A., Lehnert, M., Přidalová, M., Vařeková, R., Botek, M., \& Langer, F. (2010). Condition and body constitution of soccer players category U19 before and after completing the preparatory period. Acta Universitatis Palackianae Olomucensis. Gymnica, 40(2), 47-54.

Carron, A. V., Hausenblas, H. A., \& Eys, M. A. (2005). Group dynamics in sport (3rd ed.). Morgantown, WV: Fitness Information Technology, Inc.

Casajús, J. A. (2001). Seasonal variation in fitness variables in professional soccer players. Journal of Sports Medicine and Physical Fitness, 41(4), 463-469.

Cohen, J. (1988). Statistical power analysis for the behavioral sciences (2nd ed.). Hillsdale, NJ: Lawrence Erlbaum Associates.

da Silva Vasques, C. M., Lopes, V. P., Teixeira e Seabra, A. F., da Silva, S. P., \& Maia, J. A. R. (2006). Sibling similarities in somatotype. Brazilian Journal of Kineanthropometry \& Human Performance, 8(3), 23-29.

Dovalil, J. et al. (2002). Výkon a trénink ve sportu [Sports performance and training]. Praha: Olympia.

Forjasz, J. (2011). Somatic build of rowers in the period from 1995 to 2005. Human Movement, 12(1), 46-56.

Gil, S. M., Gil, J., Ruiz, F., Irazusta, A., \& Irazusta, J. (2007). Physiological and anthropometric characteristics of young soccer players according to their playing position: Relevance for the selection process. Journal of Strength and Conditioning Research, 21(2), 438-445.

Green, M. R., Pivarnik, J. M., Carrier, D. P., \& Womack, Ch. J. (2006). Relationship between physiological profiles and on ice performance of a national collegiate athletic association division I Hockey Team. Journal of Strength and Conditioning Research, 20(1), 43-48.

Grosser, M., \& Zintl, F. (1994). Training of the physical conditions (2nd ed.). Schorndorf: Hoffman. 
Hattori, K., Tatsumi, N., \& Tanaka, S. (1997). Assessment of body composition by using a new chart method. American Journal of Human Biology, 9(5), 573-578.

Heath, B. H., \& Carter, J. E. L. (1967). A modified somatotype method. American Journal of Physical Anthropology, 27(1), 57-74.

Hencken, C. L. (2004). Anthropometric measurement in elite football players. Journal of Sports Sciences, 22(3), 266-267.

Heyward, V. H., \& Wagner, D. R. (2004). Applied body composition assessment (2nd ed.). Champaign, IL: Human Kinetics.

Jürimäe, T., \& Jürimäe, J. (2001). Growth, physical activity and motor development in prepubertal children. Boca Raton, FL: CRC Press.

Kyle, U. G., Schulz, Y., Dupertius, Y. M., \& Pichard, C. (2003). Bodycomposition interpretation: Contributions of the fat-free mass index and the bodyfat mass index. Nutrition, 19(7-8), 587-604.

Lohman, T. G. (1989). Assessment of body composition in children. Pediatric Exercise Science, 1(1), 19-30.

Lohman, T. G. (1992). Advances in body composition assessment. Champaign, IL: Human Kinetics.

Lohman, T. G., Houtkooper, L., \& Going, S. B. (1997). Body fat measurement goes high-tech: Not all are created equal. ACSM's Health \& Fitness Journal, 7(1), 0-35.

Maffeis, C., Schena, F., Zaffanello, M., Zoccante, L., Schutz, Y., \& Pinelli, L. (1994). Maximal aerobic power during running and cycling in obese and nonobese children. Acta Paediatrica, 83(1), 113-116.

Malina, R. M., Bouchard, C., \& Bar-Or, O. (2004). Growth, maturation, and physical activity (2nd ed.). Champaign, IL: Human Kinetics.

Malone, L. A., Collins, J. M., Thompson, M., \& Barfield, J. P. (2004). The power of soccer. Palaestra, 20(2), 26-29.

Martarelli, D., Martarelli, B., \& Pompei, P. (2008). Body composition obtained from the body mass index. European Journal of Nutrition, 47(8), 409-416.

McArdle, W. D., Katch, F. I., \& Katch, V. L. (2007). Exercise physiology. Energy, nutrition, \& human performance (6th ed.). Philadelphia, PA: Williams \& Wilkins.

Moreira, S. B. (2008). The evolution of the individual factors performance in the elite of the world soccer, between 1970 and 1998. Fitness \& Performance Journal, 7(2), 107-111.

Mota, J., Guerra, S., Leandro, C., Pinto, A., Ribeiro, J. C., \& Duarte, J. A. (2002). Association of maturation, sex and body fat in cardiorespiratory fitness. American Journal of Human Biology, 4(6), 707-718.
Ostojic, S. M, Stojanovic, M., Jukic, I., Pasalic, E., \& Jourkesh, M. (2009). The effects of six weeks of training on physical fitness and performance in teenage and mature top-level soccer players. Biology of Sports, 26(4), 379-387.

Peeters, M. W., Thomis, M. A., Claessens, A. L., Loos, R. J., Maes, H. H., Lysens, R., ... Beunen, G. (2003). Heritability of somatotype components from early adolescence into young adulthood: A multivariate analysis on a longitudinal twin study. Annals of $\mathrm{Hu}$ man Biology, 30(4), 402-418.

Rampinini, E., Impellizzeri, F. M., Castagna, C., Coutts, A. J., \& Wisløff, U. (2009). Technical performance during soccer matches of the Italian series a league series: Effect of fatigue and competitive level. Journal of Science and Medicine in Sport, 12(1), 227-233.

Raschka, C., \& Wolthausen, C. (2007). Comparison of somatotype differences of soccer and handball players based on the methods of German and Anglo-American schools of constitutional biology. Anthropologischer Anzeige, 65(3), 303-316.

Rico-Sanz, J. (1998). Body composition and nutritional assessments in soccer. International Journal of Sport Nutrition and Exercise Metabolism, 8(2), 113-123.

Rush, E., Chhichhia, P., Kilding, A., \& Plank, L. (2010). Water turnover in children and young adults. European Journal of Applied Physiology, 110(6), 1209-1214.

Saar, M., \& Jürimäe, T. (2001). Influence of anthropometric parameters on motor ability test results in 13-15 year old girls. Papers on Anthropology, 5(10), 260-297.

Silvestre, R., West, C., Maresh, C. M., \& Kraemer, W. J. (2006). Body composition and physical performance in men's soccer: A study of national collegiate athletic association division I team. Journal of Strength and Conditioning Research, 20(1), 177-183.

Schnabel, G., Harre, D., \& Krug J. (2003). Training method. Performance. Training. Match (3rd ed.). Berlin: Sportsverlag.

Stolen, T., Chamari, K., Castagna, C., \& Wisloff, U. (2005). Physiology of soccer: An update. Sports Medicine, 35(6), 501-536.

Sutton, L., Scott, M., Wallace, J., \& Reilly, T. (2009). Body composition of English Premier league soccer players: Influence of playing position, international status, and ethnicity. Journal of Sports Sciences, 27(10), 1019-1026.

Viviani, F. (2001). Body image and its relationship with body composition and somatotype in adolescents. Medicine and Sport Science, 44, 104-114.

Wilmore, J. H., \& Costill, D. L. (1994). Physiology of sport and exercise. Champaign, IL: Human Kinetics. 
Zanovec, M., Johnson, L. G., Marx, B. D., Keenan, M. J., \& Tuuri, G. (2009). Self-reported physical activity improves prediction of body fatness in young adults. Medicine and Science in Sports and Exercise, 41(2), 328-335.

\section{SOMATICKÉ PARAMETRY HRÁČC̊ KOPANÉ MLÁDEŽNICKÝCH KATEGORIÍ VE VZTAHU K VÝKONNOSTI}

(Souhrn anglického textu)

VÝCHODISKA: Somatické parametry jsou zařazovány nejen do obecné struktury sportovního výkonu, ale i do struktury sportovního výkonu ve fotbale. S ohledem na tuto strukturu by měli mít hráči vy̌šši výkonnostní úrovně vhodnější somatické předpoklady pro výkon a jejich somatické parametry by se měly lišit od hráčů nižší výkonnostní úrovně.

CÍLE: Cílem studie je zhodnotit somatické parametry u hráčủ kopané různé výkonnostní úrovně.

METODIKA: Výzkum byl realizován u 90 hráčů kopané, hrajících dorostenecké soutěže. Hráči byli rozděleni do tř́i výkonnostních úrovní. U hráčủ byly sledovány základní antropometrické parametry (tělesná výška a hmotnost), somatotyp (Heath-Carter), zastoupení tělesného tuku, tukuprosté hmoty a celkové tělesné vody (metoda BIA - Tanita 418 MA). Měření všech hráčů probíhalo ve stejném roce na začátku soutěžního období. Všechna měření byla realizovaná vždy v ranních hodinách a prováděla je vždy stejná osoba s odpovídající praxí.

VÝSLEDKY: Průměrnými hodnotami základních antropometrických parametrů (tělesná výška a hmotnost) se sledované výkonnostní kategorie hráčů statisticky významně neliší. U všech sledovaných skupin odpovídají zjištěné průměrné hodnoty normovým hodnotám české populace této věkové skupiny.

V ostatních somatických parametrech se statisticky i věcně významně odlišovaly průměrné hodnoty hráčů nejnižší výkonnostní úrovně od ostatních výkonnostních úrovní. Hráči nejnižší výkonnostní úrovně měli nejvyšši tělesnou hmotnost, která je způsobena zvýšením podílu tukové složky, nikoliv tukuprosté hmoty, což se u nich také projevilo nejvyšší hodnotou procentuálního zastoupení tělesného tuku a nejnižší hodnotou tukuprosté hmoty.

ZÁVĚRY: Od střední výkonnostní úrovně (Česká republika - Moravskoslezský kraj) nepovažujeme sledované parametry tělesného složení v kontextu individuálního herního výkonu za kličové.

Klíčová slova: sportovní hry, sportovní výkon, tělesné složení, somatotyp. 